\title{
FORMATION OF COGNITIVE AUTONOMY OF STUDENTS THROUGH THE IMPLEMENTATION OF CROSS- CURRICULAR LINKS BY MEANS OF MOBILE TECHNOLOGIES
}

ФОРМУВАННЯ ПІЗНАВАЛЬНОÏ САМОСТІЙНОСТІ УЧНІВ ЧЕРЕЗ РЕАЛІЗАЦІЮ МІЖПРЕДМЕТНИХ ЗВ'ЯЗКІВ ЗАСОБАМИ МОБІЛЬНИХ ТЕХНОЛОГІЙ

Tetiana HRANOVSKA, Postgraduate student Тетяна ГРАНОВСЬКА, https://orcid.org/0000-0003-2683-839X taniya20gran@gmail.com

H.S. Skovoroda Kharkiv national pedagogical university

$\triangle 29$ Alchevskih St., Kharkiv, 61000, Ukraine
Харківський національний педагогічний університет імені Г.С. Сковороди вул. Алчевських, 29, м. Харків, 61000

Original manuscript received: October 01, 2019

Revised manuscript accepted: December 11, 2019

\section{ABSTRACT}

The article analyzes the directions of application of cross-curricular links in the modern conditions of secondary school. The experience of integration of crosscurricular links in teaching of natural subjects is characterized. The importance of the use of computer technologies in teaching natural sciences is emphasized, given their specificity. It is suggested as alternative information and communication technologies to use mobile devices during the educational process to realize cross-curricular links as a way of forming cognitive autonomy of students.

In this work the directions of realization of cross-curricular relations for teaching of natural sciences are analyzed. The author proposes tasks that can be used to establish cross-curricular links in natural-science lessons, and provides electronic resources that can be used to create cross-curricular tasks, and outlines ways to accomplish these tasks through mobile technology.

The text justifies the difficulties faced by teachers in the implementation of crosscurricular links in the teaching of natural subjects, in particular due to the inconsistency of some topics of school curricula, lack of a base of theoretical and methodological materials for the creation of cross-curricular problems for natural subjects, etc.

The article shows the positive impact of cross-curricular integration on natural science lessons to increase cognitive interest and formation of cognitive autonomy of students. It is noted that the development of cross-curricular content tasks that are appropriate to use in the educational process of natural sciences remains an urgent task. A promising area of research is the integration of cross-curricular linkages in the course of completing project tasks and participating in project activities, which has a positive impact on students' cognitive abilities.

Further exploration will be achieved through cross-curricular links in the research, taking into account the capabilities of mobile devices, both built-in (camera, 
Серія: Педагогічні науки. - Вип.3. - Бердянськ : БДПУ, 2019. - 453 с.

digital sensors) and external (mobile applications) for the formation of students' cognitive autonomy.

Key words: cognitive autonomy; cross-curricular links; tasks of cross-curricular content; subjects of the natural cycle; mobile technologies.

Постановка проблеми. Стан освітнього процесу в Україні зазнає глобальних змін, які проявляються як на державному рівні $[6,10]$, так і на особистісному, оскільки кожен учитель розуміє важливість застосування ефективних методик і підходів до навчання, які мотивуватимуть учнів до навчання й формуватимуть у них бажання вчитися.

Завдання сучасної школи спрямоване на формування компетентного учня, який не лише буде володіти великим об'ємом інформації, а й вміти застосовувати його на практиці та примножувати свої знання через самостійну пізнавальну діяльність.

Важливим моментом у вихованні самодостатньої особистості $\epsilon$, на наш погляд, формування пізнавальної самостійності, яка як інтегративна риса допоможе учню особистісно розвиватися протягом життя. Ми живемо в епоху глобальних змін, яка характеризується появою нових сучасних інформаційних технологій, що входять в усі сфери людського життя набагато швидше, ніж ми встигаємо їх опанувати та застосувати у своїй діяльності. Особливо важливо слідкувати за змінами технологій учителям природничих предметів, у яких не завжди $є$ можливість реалізувати практичні чи лабораторні роботи з допомогою обладнання кабінетів, не говорячи про мультимедійну підтримку при проведенні уроків. 3 огляду на це слід відшукувати можливості проводити урок повноцінно і застосовувати при цьому різноманітний набір засобів інформаційно-комунікаційних технологій.

Аналіз останніх досліджень і публікацій. Дослідженням упровадження міжпредметних зв'язків у процесі навчання присвячені роботи: Н. Захарової, І. Звєрєва, Д. Кирюшкіна, Н. Лесняк, В. Максимової, Ю. Мальованого, Е. Моносзона, М. Скаткіна, О. Тесленко та ін.

Особливостями встановлення міжпредметних зв'язків між предметами природничого циклу займалися С. Величко, М. Голобородько, С. Гончаренко, В. Зав'ялов, В. Ільченко, О. Кабардін, Ю. Лук'янов, 3. Сичевська, А. Сільвейстр, Ф. Соколова, Н. Стучинська, О. Усова, В. Федорова, Н. Шефер, В. Шуман.

На сучасному етапі розвитку наук процес інтеграції природничих предметів є повністю виправданим, оскільки вони розширюють свої межі та напрями досліджень. При цьому їх розвиток відбувається в єдності 3 навколишнім світом для одержання фундаментальних знань про природу, які $\epsilon$ важливими для формування у свідомості учнів природничо-наукової картини світу [4, с. 9]. Використання міжпредметних зв'язків у процесі навчання природничих дисциплін сприяє кращому їх розумінню та засвоєнню (Сільвейстр, 2013).

Встановлення міжпредметних зв'язків розвиває системне мислення учнів, сприяє формуванню конкретних знань учнів та передбачає застосування методів (абстрагування, моделювання, аналогія, узагальнення) (Гончаренко, 1997: 210). Знання, отримані на 
основі встановлення міжпредметних зв'язків, мають стати основою для розв'язання комплексних пізнавальних завдань, які, в свою чергу, розвивають мотиваційну та когнітивну сфери особистості учня (Капарнік, 2011). Зазначені дослідження спрямовані на аналіз впливу міжпредметних зв'язків на пізнавальні можливості учнів. Проте науковці у своїх дослідженнях застосовують проблемний виклад та виконання традиційних завдань, при цьому не занурюючись у можливості засобів інформаційно-комунікаційних технологій, які здатні підвищити цікавість учнів до вивчення предметів і стати незамінними атрибутами для виконання пізнавальних завдань міжпредметного змісту.

Мета статті проаналізувати вплив міжпредметних зв'язків на формування пізнавальної самостійності в учнів основної школи при вивченні природничих наук з використанням мобільних технологій.

Для того, щоб учень став активним учасником освітнього процесу, його необхідно залучати до навчально-пізнавальної діяльності, яка може бути реалізована з використанням мобільних технологій, що мають значну кількість можливостей для навчання усіх предметів без винятку через існування мобільних навчальних додатків. Учителі намагаються застосовувати їх у своїй діяльності, але використання мобільних технологій під час вивчення природничих наук потребує більш детального дослідження.

У процесі навчання природничих дисциплін в учнів має формуватися комплекс предметних знань, які вони ідентифікують як набуті при вивченні окремого предмета, але розуміючи існування взаємозв'язків з іншими дисциплінами. 3 огляду на це важливим стає застосування міжпредметних зв'язків для фоормування пізнавальної самостійності учнів.

У навчанні предметів природничого напряму міжпредметні зв'язки можуть бути реалізовані в таких напрямах:

- створення проблемних ситуацій, що потребують використання знань й умінь інших навчальних дисциплін. Таким $€$ проблемне навчання (Мілевська, 2014), в основі якого лежить вирішення проблеми та отримання нових знаньна основі аналізу раніше вивченого матеріалу. Наприклад, при вивченні теми "Поняття про періодичну систему хімічних елементів Д. Менделєєва" можна запитати про походження назв елементів. У цьому випадку встановлюються міжпредметні зв'язки між хімією і географією;

- виконання завдань міжпредметного змісту, які спираються на попередньо вивчений матеріал інших шкільних дисциплін. Це можуть бути завдання на виправлення помилок, наприклад, планета Земля на дві третини покрита сірчаною кислотою; живі організми дихають азотом, а поглинають сірководень; у кістках тварин і людей $є$ аргон і т.д. У цьому випадку залучені знання із географії, біології, екології тощо. Завдання можуть бути досить простими і підвищеної складності, наприклад, "Опишіть будову кімнатної рослини “Товстянка" (грошове дерево). Про що свідчить будова листка цієї рослини? До яких умов життя ця рослина пристосована, з чого це видно?". Такі завдання вимагають не лише фундаментальних знань з розділу біології, ботаніки, а й географрії, особливостей кліматичних умов та природних зон, які впливають на 
рослинність планети. А якщо розширити питання про склад речовин листка чи особливості живлення рослини, то поринемо в хімічні та фрізичні процеси. Такі завдання розширюють кругозір учнів, змушують їх міркувати та фрормують пізнавальну самостійність під час пошуку інформації для виконання завдання;

- виконання проєктних завдань, зокрема у межах STEM-освіти, яка ґрунтується на інтегрованій дослідницькій, творчій діяльності учнів. STEMнавчання в одному зі своїх проявів передбачає застосування уроків зі встановленням міжпредметних зв'язків, сприятливих для формування в учнів цілісного світогляду, а також особистісного ставлення до конкретних проблем заняття. 3 метою перевірки саме предметних знань, умінь і навичок учитель спирається на певну систему інтегрованих завдань, змодельованих із життєвих ситуацій [8]. У межах виконання проєктних завдань учні спрямовують свою діяльність на одержання особистісно важливих результатів дослідження, вони можуть самостійно встановлювати рівень занурення в навчання й обирати способи вирішення проблеми.

Встановлення міжпредметних зв'язків при вивченні природничих предметів потребує вирішення великої кількості специфічних завдань проблемного інтегрованого змісту, які повинні викликати пізнавальний інтерес в учнів під час їх виконання. Дослідження сучасних педагогів і наш особистий досвід дає підставу стверджувати, що завдання, які пропонується виконати з допомогою електронних ресурсів, викликають більший інтерес, ніж просто на папері. При цьому важливого значення набуває навчання кожного учня, яке потребує надання однакових можливостей і доступу до необхідних IКТ. Такими можуть бути мобільні смартфони та планшети, які $€$ доступними, багатофункціональними пристроями. Для реалізації міжпредметних зв'язків можна користуватися потужним інструментарієм мобільних технологій, а точніше їх засобами: вбудованими інструментами (камера, диктофон, гарнітура, ліхтарик), мобільними додатками і мобільними датчиками (вимірювання показників температури, тиску, кута нахилу тощо), які стануть незамінними під час уроків і участі у проєктній діяльності.

Завдання міжпредметного змісту засобами мобільних технологій можуть можуть реалізуватися створенням завдань з допомогою Інтернетсервісів, (https://learningapps.org/, https://naurok.com.ua), які можна виконувати в режимі онлайн 3 персонального мобільного пристрою, наприклад, сортування понять з різних предметів або встановлення їх відповідності та характеристик (рис. 1)
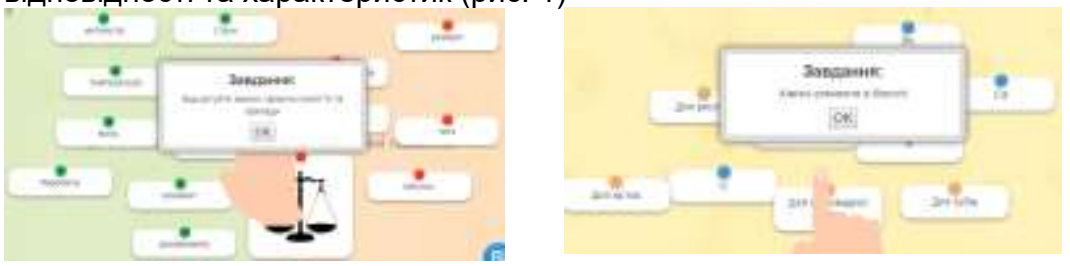

Рис. 1. Приклад завдань міжпредметного змісту 
Цікаві міжпредметні завдання можна створити за допомогою флеш-карток. Принцип роботи таких засобів навчання полягає у фрормуванні питання на електронній картці, де з однієї сторони пишеться запитання, а з іншої - відповідь. Учень бачить запитання, усно дає на нього відповідь, а щоб дізнатися відповідь, натискає на кнопку, яка перевертає картку й показує правильну відповідь. Такий вид робіт підвищується активність на уроці, а також тренує увагу і пам'ять учнів. Флеш-картки можна застосовувати для одночасної роботи з усіма учнями класу; відповіді учні можуть давати одночасно, хто швидше або по черзі, навіть можливе самостійне виконання тренувальних завдань. Для виконання такого завдання учителю слід надати електронне посилання учням будь-яким можливим способом (через месенджер, електронну пошту aбо QR-код). Приклад виконання такого завдання з допомогою мобільного пристрою поданий на рис.2.

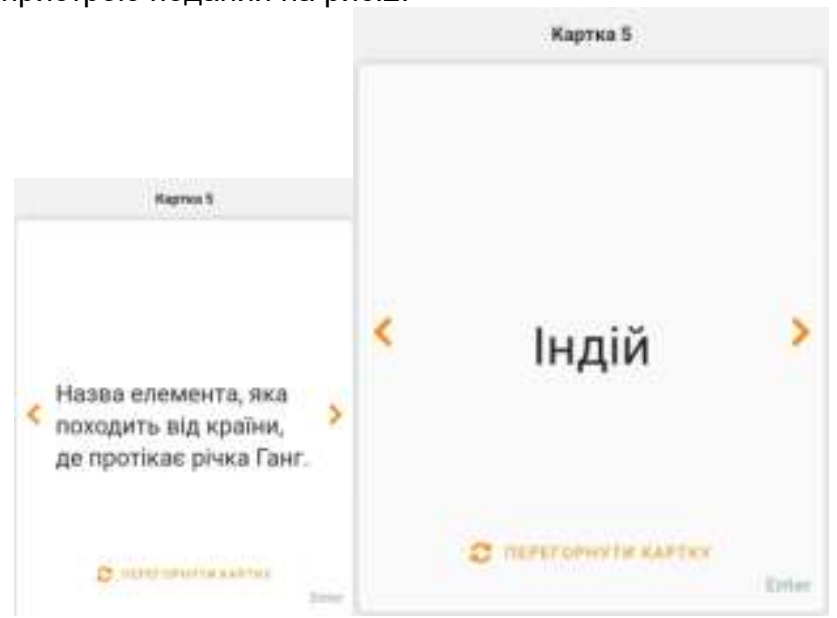

\section{Рис. 2. Приклад флеш-картки з завданням міжпредметного змісту}

Такі картки можна створювати засобами Інтернет-сервісів й за допомогою мобільних додатків, наприклад, Flashcards Maker [1]. Можна давати завдання учням на створення карток, які сприятимуть розвитку уяви учнів і міркувань щодо взаємозв'язків між конкретними поняттями та об'єктами різних предметів.

Безпосереднє використання мобільних додатків, аналіз розробок на Google Play показав, що на сервері $є$ додатки різного наповнення й призначення для вивчення окремих предметів чи тем, але навчальних додатків інтегрованого змісту немає. Проте $€$ велика кількість ігрових додатків різного призначення. Саме з їх допомогою можна створювати тестування $з$ запитаннями міжпредметного контенту. Наприклад, 3 допомогою мобільних додатків "TestMarket"[3], "Testity [2] - створи свій власний тест", можна створювати тести на смартфоні чи планшеті, 
Серія: Педагогічні науки. - Вип.3. - Бердянськ : БДПУ, 2019. - 453 с.

залучати учасників до проходження опитувань як у реальному часі, так і офлайн.

Можна подавати завдання в більш широкому вигляді для творчого виконання. Учням пропонується перевести двійковий код і визначити мобільний номер телефона за допомогою конретного он-лайн калькулятора, вихід на який закодовано в Qr-коді. Учні дзвонять на встановлений номер, де отримують наступне з необхідної теми курсу хімії чи фізики тощо. Результат завдання $€$ підказкою для виконання іншого і таку діяльність можна реалізувати з допомогою смартфонів учнів. Таким чином, завдання подаються у вигляді квесту (Тернова А.С., 2019).

Слід зазначити, що на сьогоднішній день реалізація міжпредметних зв'язків шкільних предметів $€$ утрудненою через кілька факторів: неузгодженість певних тем шкільних програм окремих предметів, зокрема хімії та фрізики, хімії та біології; складність об'єднання зусиль учителівпредметників для організації проєктної роботи учнів; недостатність методико-дидактичного матеріалу міжпредметних зв'язків у навчанні учнів природничих дисциплін, зокрема конкретних міжпредметних завдань, вузька спрямованість завдань міжпредметного змісту.

Висновок. Аналіз застосування міжпредметних зв'язків у навчанні природничих предметів має велике значення для формування в учнів цілісної картини світу. Міжпредметні зв'язки реалізуються у своїй більшості через використання проблемних ситуацій, які $€$ важливими методами навчання, проте вони не завжди вирішуються учнями в повному обсязі. 3 огляду на це вважаємо важливим формування інтересу до навчання через застосування електронних завдань міжпредметного змісту засобами мобільних технологій.

Застосування міжпредметних зв'язків дає змогу урізноманітнити освітній процес конкретного предмета та підвищити інтерес учнів до навчання, сорормувавши пізнавальну самостійність до вивчення природничих наук завдяки засобам мобільних технологій. Під час виконання завдань з допомогою мобільних пристроїв учні навчаються критично мислити, узагальнювати матеріал, робити висновки та здобувати нові знання з предметів. Крім того, виникає потреба розробки завдань міжпредметного змісту, які доцільно буде застосовувати в навчанні конкретного предмета з допомогою мобільних технологій.

\section{Література}

1.Flashcards Maker. [Електронний ресурc] / Google Play. - Режим доступу:https://play.google.com/store/apps/details?id=com.ubacoda.fashcards

2. Testity - створи свій власний тест. [Електронний ресурс] / Google Play. Режим доступу:https://play.google.com/store/apps/details?id= com.sergeyyaniuk. testity\&hl=uk

3. TestMarket. [Електронний pecypc]/Google Play. - Режим доступу: https://play.google.com/store/apps/details?id=jp.gr.java conf.foobar.testmaker.service\&hl=uk

4.Активні форми та методи навчання біології : [навч. посіб. / уклад. К.М. Задорожний]. - Х. : Основа, 2008. - 123 с.

$376 \mathrm{c}$.

5.Гончаренко С. Український педагогічний словник. - К.: Либідь, 1997. - 


\section{Наукові записки БДПУ (http://bdpu.org/pedagogy/ua/)}

6.Закон України Про освіту: за станом на 09.08.2019, підстава - 2745-VIII / (Відомості Верховної Ради (ВВР), 2017, № 38-39, ст.380. Режим доступу: https://zakon.rada.gov.ua/laws/show/2145-19

7.Капарнік Б. Реалізація міжпредметних зв'язків. Проблемний підхід. I Б. Капарнік // Психолого-педагогічні проблеми сільської школи. - 2011. - № 39. C. $117-122$.

8.Методичні рекомендації щодо розвитку STEM-освіти у закладах загальної середньої та позашкільної освіти у 2019/2020 навчальному році. [Електронний ресурс] / Лист ІМЗО № 22.1/10-2876 від 22.08.19p. - Режим доступу: https://osvita.ua/legislation/Ser osv/65463/

9.Мілевська С.Я. Активізація пізнавальної діяльності учнів на уроках хімії / С.Я. Мілевська// Основа. - 2014. № 5-6 (305-306), березень. - С. 2 - 8.

10. Нова українська школа. Концептуальні засади реформування середньої школи [Електронний ресурс] / Гриневич Л., Елькін О., Калашнікова С. та ін.; під ред. Грищенко М. Міністерство освіти і науки України, 2016. - 34 с. - Режим доступу: https://mon.gov.ua/storage/app/media/zagalna\%20serednya/nova-ukrainskashkola-compressed.pdf

11. Сільвейстр А.М. Реалізація міжпредметних зв'язків під час навчання фізики, хімії і біології у школі/ А.М. Сільвейстр // Вісник Чернігівського національного педагогічного університету. Педагогічні науки. - 2013. - Вип. 109. C. $110-113$.

12. Тернова А.С. Застосування закону збереження імпульсу в ракетобудуванні. [Електронний ресурс] / - А.С. Тернова. - Режим доступу: https://naurok.com.ua/urok kvest-zastosuvannya-zakonu-zberezhennya-impulsu-vraketobuduvanni-10-klas-90967.html

\section{References}

1. Flashcards Maker. [Elektronny`j resurs] / Google Play. - Rezhy`m dostupu:https://play.google.com/store/apps/details?id=com.ubacoda.fashcards

2. Testity - stvory svij vlasny`j test. [Elektronny`j resurs] / Google Play. - Rezhy`m dostupu:https://play.google.com/store/apps/details?id=com.sergeyyaniuk. testity\&hl=uk

3. TestMarket. [Elektronny`j resurs]/Google Play. - Rezhy`m dostupu: https://play.google.com/store/apps/details?id=jp.gr.java conf.foobar.testmaker.service\& $\underline{\mathrm{hl}=\mathrm{uk}}$

4. Akty`vni formy` ta metody` navchannya biologiyi : [navch. posib. / uklad. K.M. Zadorozhny'j]. - X. : Osnova, 2008. - 123 s.

5. Goncharenko S. Ukrayins 'ky’j pedagogichny’j slovny’k. - K.: Ly’bid', 1997. - 376 s.

6. Zakon Ukrayiny` Pro osvitu: za stanom na 09.08.2019, pidstava - 2745-VIII I (Vidomosti Verxovnoyi Rady` (VVR), 2017, \# 38-39, st.380. Rezhy`m dostupu:https://zakon.rada.gov.ua/laws/show/2145-19

7. Kaparnik B. Realizaciya mizhpredmetny`x zv'yazkiv. Problemny`j pidxid. / B. Kaparnik // Psy`xologo-pedagogichni problemy` sil`s`koyi shkoly`. - 2011. - \# 39. C. $117-122$.

8. Metody`chni rekomendaciyi shhodo rozvy`tku STEM-osvity' u zakladax zagal'noyi seredn`oyi ta pozashkil'noyi osvity' u 2019/2020 navchal'nomu roci. [Elektronny`j resurs] / Ly`st IMZO \# 22.1/10-2876 vid 22.08.19r. - Rezhy`m dostupu: https://osvita.ua/legislation/Ser osv/65463/

9. Milevs`ka S.Ya. Akty vizaciya piznaval’noyi diyal’nosti uchniv na urokax ximiyi / S.Ya. Milevs`ka// Osnova. - 2014. \# 5-6 (305-306), berezen`. - S. 2 - 8.

10. Nova ukrayins`ka shkola. Konceptual'ni zasady` reformuvannya seredn`oyi shkoly` [Elektronny`j resurs] / Gry’nevy`ch L., El’kin O., Kalashnikova S. ta in.; pid red. Gry`shhenko M. Ministerstvo osvity` i nauky` Ukrayiny`, 2016. - 34 s. - Rezhy`m 
Серія: Педагогічні науки. - Вип.3. - Бердянськ : БДПУ, 2019. - 453 с.

dostupu: https://mon.gov.ua/storage/app/media/zagalna\%20serednya/nova-ukrainskashkola-compressed.pdf

11. Sil'vejstr A.M. Realizaciya mizhpredmetny 'x zv'yazkiv pid chas navchannya fizy`ky', ximiyi i biologiyi u shkoli / A.M. Sil'vejstr // Visny’k Chernigivs`kogo nacional’nogo pedagogichnogo universy`tetu. Pedagogichni nauky`. - 2013. - Vy’p. 109. - S. 110-113.

12. Ternova A.S. Zastosuvannya zakonu zberezhennya impulsu v raketobuduvanni. [Elektronny`j resurs] / - A.S. Ternova. - Rezhy'm dostupu: https://naurok.com.ua/urok kvest-zastosuvannya-zakonu-zberezhennya-impulsu-vraketobuduvanni-10-klas-90967.html

\section{АНОТАЦІЯ}

У статті проаналізовано напрями застосування міжпредметних зв'язків у сучасних умовах основної школи. Охарактеризовано досвід інтеграції міжпредметних зв'язків у навчанні природничих предметів. Зазначено важливість застосування комп'ютерних технологій при викладанні природничих дисциплін з огляду на їхню специфріку. Запропоновано як альтернативні інформаційно-комунікаційні технології використовувати засоби мобільних пристроїв під час освітнього процесу для реалізації міжпредметних зв'язків, що сприятиме формуванню пізнавальної самостійності учнів.

У роботі проаналізовано напрями реалізації міжпредметних зв'язків для викладання природничих наук. Автором запропоновано завдання, які доцільно застосовувати для встановлення міжпредметних зв'язків на уроках дисциплін природничого циклу, запропоновано сервіси електронних ресурсів, які можна використовувати для створення міжпредметних завдань, а також вказані шляхи виконання їх з допомогою мобільних технологій.

Обгрунтовано труднощі, з якими стикаються вчителі під час впровадження міжпредметних зв'язків при навчанні природничих предметів, зокрема через неузгодженість деяких тем икільних програм, недостатність бази теоретично-методичних матеріалів для створення міжпредметних завдань з природничих предметів тощо.

Доведено позитивний вплив міжпредметної інтеграції на уроках природничих предметів для підвищення пізнавального інтересу та фрормування пізнавальної самостійності учнів. Зазначено, що актуальним завданням залишається розробка завдань міжпредметного змісту, які доцільно застосовувати у освітньому процесі природничих наук. Перспективним напрямом дослідження залишається інтеграція міжпредметних зв'язків у ході виконання проєктних завдань та участі в такій діяльності, яка позитивно впливає на пізнавальні можливості учнів.

Подальших розвідок набуде реалізація міжпредметних зв'язків у дослідницькій діяльності з урахуванням можливостей засобів мобільних пристроїв, як вбудованих (камера, цифрові датчики), так і зовнішніх (мобільні додатки) для формування пізнавальної самостійності учнів.

Ключові слова: пізнавальна самостійність; міжпредметні зв'язки; завдання міжпредметного змісту; предмети природничого циклу; мобільні технології. 